\title{
FAKE NEWS À LUZ DA RESPONSABILIDADE CIVIL DIGITAL: O SURGIMENTO DE UM NOVO DANO SOCIAL
}

\author{
Glayder Daywerth Pereira Guimarães \\ Escola Superior Dom Helder Câmara - ESDHC, Minas \\ Gerais. \\ glayderdaywerthpg@live.com \\ Michael César Silva \\ Escola Superior Dom Helder Câmara - ESDHC, Minas \\ Gerais. \\ michael@adv.oabmg.org.br
}

\begin{abstract}
RESUMO: A pesquisa tem por objetivo analisar a responsabilidade civil digital, sob o prisma do direito dos danos, com enfoque relacionado a divulgação de Fake News, verificando-se a existência, ou não, de danos diversos advindos da conduta de disseminar notícias falsas. Neste estudo, buscou-se evidenciar as implicações das Fake News, principalmente, no que se refere a pós verdade, abordando a temática da liberdade de expressão, bem como as hipóteses de abuso do direito, no ordenamento jurídico brasileiro, culminando na temática dos novos danos. A pesquisa proposta pertence à vertente metodológica jurídico-sociológica. No tocante ao tipo de investigação foi escolhido, na classificação Witker (1985) e Gustin (2010), o tipo jurídico-projetivo. De acordo com a técnica de análise do conteúdo, afirma-se que se trata de uma pesquisa teórica, o que se mostrou possível a partir da análise de conteúdo da doutrina, jurisprudência e legislação pertinente. Por fim, restou determinado que as Fake News se inserem como elemento ocasionador de danos, não somente morais ou materiais, sendo vislumbrável a hipótese de danos sociais em função do resultado da conduta de disseminação de notícias falsas na sociedade contemporânea.
\end{abstract}

PALAVRAS-CHAVE: Responsabilidade civil. Direito dos danos. Internet. Fake News. Pós Verdade.

Fake news and post truth in the light of digital civil liability: the arise of a new social damage

ABSTRACT: The objective of this study was to analyze the issue of digital civil liability under the prism of the right of damages with regard to Fake News, verifying the existence, or not, of various damages arising from the conduct of disseminating fake news. This paper seeks to highlight the implications of Fake News, especially with regard to Post Truth, addressing the issue of freedom of speech, as well as the hypothesis of abuse of the right, in the Brazilian legal system, culminating in the issue of new damages. The research belongs to the juridical-sociological methodological aspects. Regarding the type of research was chosen the Witker (1985) and Gustin (2010), the juridical-projective type. According to the analysis of the technical content, it's stated that it's a theoretical research, which was possible from the content analysis of the doctrine, jurisprudence and relevant legislation. It remains determined that Fake News are inserted as a causal element of damages, not only moral or material, being the hypothesis of social damages verified in function of the result of the conduct of disseminating false news.

KEYWORDS: Civil liability. Right of Damages. Internet. Fake News. Post Truth. 


\section{INTRODUÇÃO}

A presente pesquisa fundamenta-se na análise crítica e construtiva relacionada à responsabilidade civil no âmbito digital, notadamente, no tocante à propagação das chamadas Fake News, com enfoque na questão da natureza do dano produzida pela disseminação das notícias falsas. Ressalta-se a crescente atenção em âmbito, nacional e internacional, no que se refere à disseminação de Fake News, bem como seus impactos na sociedade contemporânea.

O estudo objetiva investigar e analisar as Fake News sob a ótica do fenômeno comunicacional contemporâneo, perpassando a origem e semântica do termo nuclear do estudo, Fake News, bem como, suas implicações no que se refere a Post Truth. Ademais, propõem-se examinar as questões concernentes à liberdade de expressão e hipóteses de abuso do referido direito no ordenamento jurídico brasileiro, com a finalidade de se proceder a investigação da possibilidade de imputação de responsabilidade civil no âmbito digital a partir da compreensão da temática sobre a perspectiva dos novos danos.

A questão proposta mostra-se presente no cotidiano de todas as pessoas, haja vista que se vive em um período de digitalização e alterações sociais em função das novas tecnologias. Falar em internet, redes sociais e Fake News envolve certo truísmo, contudo mostra-se necessário na medida em que o Direito deve regular as relações sociais havidas entre os sujeitos. As Fake News, nos últimos anos, tomaram grande notoriedade, sendo notável casos em que sua utilização causou severos danos a outros sujeitos.

Em vista da consecução da pesquisa, restou delimitada a problemática relativa a extensão dos danos ocasionados pelas Fake News, de modo que, pretende-se analisar o tema sob a ótica do Direito dos Danos.

A partir das reflexões preliminares, é possível afirmar que Fake News são notícias falsas, criadas com o intuito de moldar a opinião pública sobre determinado assunto ou causar danos a determinados sujeitos, sendo perceptível sua utilização quase que irrestrita nas redes sociais, espaços de ampla divulgação e comunicação. O fenômeno das Fake News decorre de motivos sociais, tais como a alteração no polo informacional com o advento das redes sociais, o amplo acesso à internet e o massivo compartilhamento de informações e dados nesses espaços. Importante ressaltar que, a numerosa criação de dados apresenta efeitos positivos e negativos, podendose citar a protagonização dos sujeitos na internet como aspecto positivo e a dificuldade na verificação da autenticidade dos fatos relatados na internet, como efeito negativo. Sob esta ótica, há de se ter em mente que, a contrario sensu do que se presume, a internet não confere um espaço de liberdade irrestrita, sendo que os sujeitos podem ser chamados a responder caso causem danos a outrem no ambiente virtual.

No que se refere ao dano causado pelas Fake News, entende-se que, via de regra, é pessoal, direcionando-se a determinados sujeitos e disseminando informações inverídicas a respeito destes. No entanto é possível afirmar que a disseminação de Fake News se insere, hodiernamente, como uma atividade produtora de danos diversos, sendo possível a verificação de danos morais, materiais e sociais a depender das características do caso concreto.

A pesquisa a ser realizada pertence à vertente metodológica jurídico-sociológica. No tocante ao tipo de investigação, foi escolhido, na classificação Witker (1985) e Gustin (2010), o tipo jurídico-projetivo. De acordo com a técnica de análise do conteúdo, afirma-se que se trata de uma pesquisa teórica, o que será possível a partir da análise de conteúdo da doutrina e legislação pertinente. 
Por fim, o estudo propõe lançar luzes sobre a temática proposta com a finalidade de apresentar soluções adequadas no tocante a imputação de responsabilidade civil pela disseminação das Fake News, na sociedade digital contemporânea.

\title{
1. A ERA Das COMUNiCAÇÕeS
}

A sociedade contemporânea - plural, complexa e assimétrica - sofreu inúmeras alterações, mudanças estruturais desencadeadas pelas novas tecnologias que surgiram com o decurso do tempo. As novas tecnologias propiciaram uma metamorfose cultural em um curto espaço de tempo, modificando de forma singular a vida das pessoas.

Fabiano Simões Corrêa (2013, p. 14-19) elucida que com o advento do século XXI a sociedade vislumbrou, de modo ímpar, modificações, espantosas, em relação aos séculos posteriores, uma vez que a era da tecnologia propiciou, de forma célere, uma série de evoluções e revoluções até então inobservadas. Dentre essas, destaca-se, a revolução digital, a qual possibilitou a criação de novos meios de comunicação, bem como, a difusão de informações, notícias e dados.

Similarmente, Dirceu Pereira Siqueira e Danilo Henrique Nunes (2018, p. 130) esclarecem:

\begin{abstract}
A revolução digital propiciou um contexto no qual as pessoas estão aptas a exercer uma comunicação muito mais dinâmica e célere com as outras pessoas (segundo elemento - Comunicação Digital), o que não ocorria em épocas anteriores, com a comunicação por cartas ou mesmo com a comunicação pelos telefones fixos, por exemplo. As novas opções de comunicação digital alteraram significativamente o modo como as pessoas se comunicam na atualidade. Uma vez que todos contemplam oportunidades de se comunicar e colaborar com qualquer pessoa, em qualquer momento e em qualquer lugar, é necessário versar sobre as decisões apropriadas para cada momento e opção advinda da comunicação digital;
\end{abstract}

O homem sempre buscou formas de se comunicar, seja por meio de imagens, escritos, símbolos, sinais visuais ou sonoros. A interlocução entre sujeitos sempre teve seu espaço na vida das pessoas. Entretanto, no século XXI a comunicação passou por um processo de remodelação e redefinição. A digitalização criou assim um novo modelo de sociedade, pautada por novos paradigmas comunicacionais.

Segundo Michele Marinho da Silveira et al. (2010), atualmente, vive-se um período de digitalização, de transição do analógico para o digital, sendo que as gerações que viveram em maior parte antes da criação da internet interagem com o mundo de modo distinto daqueles que nasceram na fase de transição de épocas. Nessa linha de intelecção, as gerações que nasceram após a virada do século XX para XXI se relacionam com os meios digitais de forma diferenciada em relação aos grupos anteriores. A assimilação, facilidade e naturalidade com a qual as novas gerações se conectam com os meios digitais evidencia uma mudança permanente no staus quo sociocultural.

Ainda hoje, anos após o início da digitalização, verifica-se a existência de um grande número de pessoas que ainda não se utilizam das novas tecnologias, pessoas nascidas via de regra antes do surgimento de tais inovações, que por uma série de motivos preferem abster-se de participar de tal processo. Concorrentemente, vislumbram-se muitos sujeitos que buscam integrar-se ao universo digital, seja por meio de redes sociais, de blogues e até mesmo de sites de compartilhamento de vídeos. 
Fake news à luz da responsabilidade civil digital: o surgimento de um novo dano social

Luiz Fernando Afonso (2018) assevera que a tecnologia, em especial a internet, já é uma realidade ao redor do mundo, incluso o Brasil. Sendo que, em verdade, o Brasil possui um dos maiores mercados de consumo de tecnologia e de internet do mundo. Afirma ainda, que a internet e as tecnologias digitais, se inseriram em todas as esferas da vida das pessoas, sendo, inclusive, objeto de consumo dos cidadãos.

Uma das mudanças mais relevantes oportunizadas pela era digital diz respeito a disseminação de informações, notícias e dados pela internet. De acordo com um estudo promovido pela IBM Marketing Cloud (2017), 90\% dos dados contidos na internet foram criados a partir de 2016. Pessoas, empresas e dispositivos tornaram-se "fábricas de dados", disseminando numerosas informações na rede digital diariamente.

O Jornal The Wall Street Journal (2017) publicou notícia na qual divulgou que ao redor do mundo os usuários do youtube gastam, em média, mais de 1 (um) bilhão de horas por dia assistindo a vídeos na plataforma. Considerando que cada ano se tem aproximadamente 8.760 horas, seriam necessários mais de 114.155 anos para que uma pessoa assistisse o conteúdo veiculado no youtube em um mero dia. Nunca se produziu tanta informação quanto nos dias de hoje, de modo tão célere e por pessoas tão diversificadas.

Com a popularização do mundo digital e o papel cada vez mais relevante dos usuários
não só no consumo, mas na própria produção de conteúdo (os chamados "produmi-
dores"), a centralidade das organizações aos poucos perde seu valor. Esse fato se dá
acima de tudo porque aquele "contato interrompido" entre emissor (grandes empre-
sas jornalísticas) e receptor (público geral), que caracterizava a esfera pública na so-
ciedade das organizações, volta a restabelecer. Com as redes sociais, a produção de
informação nova, pode-se dar de forma desvinculada das organizações jornalísticas,
ou seja, da interação entre o emissor e o receptor, interação entre leitores em blogs,
em posts no Facebook etc. Isso, sem que a informação produzida de modo pulveri-
zado perca seu alcance, que não só tem profusão abrangente, como também tem sua
eficácia ampliada pela possibilidade de direcionamento para públicos específicos.
(MARANHÃO; CAMPOS, 2018, p. 221)

A internet viabilizou uma inversão singular no que se refere ao polo de produção e emissão de informações, dados e notícias, de modo que, o homem comum, fez-se ser ouvido. Paulatinamente, as grandes mídias perdem espaço para meios de informação descentralizados, tal como, páginas em redes sociais que realizam publicações de modo quase imediato em relação ao evento veiculado.

\section{2. (DES)INFORMAÇÃO: O FENÔMENO DAS FAKE NEWS}

A contrario sensu do que se presume, as Fake News não são um fenômeno moderno, de modo que, segundo o historiador Robert Darnton, em entrevista concedida ao jornal Folha de São Paulo, existem ao menos desde o século VI.

As notícias falsas sempre existiram. Procípio foi um historiador bizantido famoso por
escrever histórias do império de Justiniano. Mas ele também escreveu um teto se-
creto, chamado "Anekdota", e ali ele espalhou "fake News", arruinando completa-
mente a reputação do imperador Justiniano e de outros. (FOLHA DE SÃO PAULO,
2017)

Os últimos anos foram em grande medida marcados pelo termo Fake News, uma vez que a expressão encabeçou algumas das notícias mais relevantes destes anos, e possibilitaram uma profunda modificação nos meios digitais e, de modo indireto, no mundo. As Fake News se apresentam como uma releitura do antigo fenômeno social da "mentira", remodelado, a fim de se 
amoldar as mudanças sociotecnológicas do século XXI. Ao passo que no passado se manifestavam por escritos, ou pela oralidade, hoje se disseminam por meio da internet, em especial, por meio das redes sociais, meios de comunicação com polos de informação descentralizados.

O Dicionário Collins da Língua Inglesa (2017) define Fake News como representações de informações falsas, normalmente sensacionalistas, disseminadas sob o disfarce de reportagens de notícias. ${ }^{1}$

Chiara Spadaccini de Teffé e Carlos Affonso Pereira de Souza (2019, p. 542) esclarecem sobre a disseminação de Fake News, que:

\begin{abstract}
A divulgação de informações falsas ou distorcidas não é um problema novo, mas a disseminação em massa desse conteúdo através da Internet e seu impacto na política vêm chamando atenção. Após 2016, com as diversas notícias falsas divulgadas durante as eleições norte-americanas e as discussões sobre o referendo que decidiu pela saída da Grã-Bretanha da União Europeia, verificou-se a emergência de se entender o que seriam as chamadas fake news e como elas poderiam ser combatidas sem se prejudicar as liberdades fundamentais e a diversidade de opiniões.
\end{abstract}

Um dos exemplos mais notórios da disseminação de Fake News ocorreu, no ano de 2017, nos Estados Unidos da América. ${ }^{2}$

[...] A 20th Century Fox trabalhou com uma editora de notícias falsas para criar cinco sites, com nomes como o houston leader, que foram projetados para imitar fontes tradicionais de notícias online. Os sites publicaram artigos com informações falsas sobre figuras públicas proeminentes (ex: Lady Gaga e o Presidente Donald J. Trump) e temas polêmicos de interesse público (ex: saúde mental e vacinação) e foram amplamente divulgados via facebook. Em meados de fevereiro de 2017, foi descoberto (com fortes críticas populares) que a 20th Century Fox orquestrou a criação dessas publicações falsas em um esforço para divulgar o longa-metragem da fox ' $a$ cure for wellness', incluindo referências ao enredo filme e hashtags promocionais, tais como \#cureforwellness nos artigos. (KLEIN; WUELLER, 2017, tradução nossa)

No caso em questão, a empresa disseminou uma série de Fake News em sites diversos, com nomes similares a de sites de notícia de prestígio, para deste modo, encobrir o falseamento das notícias veiculadas.

As Fake News, como fenômeno de profundas repercussões sociais e potencial produção de danos diversos, se apresentam, portanto, como uma conduta ludibriosa, realizada com o intento de produção de danos por meio da dissimulação da verdade dos fatos. Nesse sentido, merece atenção dos operadores do direito e dos legisladores em vista da proteção dos direitos da personalidade e da dignidade da pessoa humana.

\footnotetext{
"False, often sensational, information disseminated under the guise of news reporting" (COLLINS, 2017)

2 20th Century Fox worked with a fake news publisher to create five Web sites, with names such as the Houston Leader, which were designed to imitate traditional online news sources. The Web sites published articles featuring false information about prominent public figures (e.g., Lady Gaga and President Donald J. Trump) and controversial topics of public interest (e.g., mental health and vaccinations) and were shared widely via Facebook. In mid-February 2017, it was discovered (to sharp public criticism) that 20th Century Fox had orchestrated the creation of these fake news publications in an effort to publicize the Fox feature film "A Cure for Wellness," by including plot references to the film and promotional hashtags such as \#cureforwellness in the subject articles. (KLEIN; WUELLER, 2017)
} 


\subsection{Quando as Fake News se tornam verdade}

Para além das Fake News, situa-se a Post Truth, fenômeno social, que com o advento das redes sociais, em especial o facebook, tomou notoriedade e, consequentemente, teve seu debate intensificado.

Segundo o Dicionário Oxford da Língua Inglesa (2016) Post Truth ou a "pós-verdade" relaciona-se à circunstância na qual os fatos objetivos têm menor influência em moldar a opinião pública do que aqueles que apelam a emoções e crenças pessoais. ${ }^{3}$

A internet, em especial, as redes sociais, uma vez que se estabelecem como centros de comunicação conjunta entre indivíduos, se apresentam como meios ideais para o vislumbramento da Post Truth. As redes sociais, tais como Facebook ou Twitter, cotidianamente, são inundadas com milhares de publicações, muitas delas munidas de Fake News, as quais impulsionam a Post Truth, dado o usual caráter político das notícias vinculadas.

Sobre a temática do volumoso compartilhamento de dados e informações na internet, conexo à temática das Fake News e da Post Truth é necessária atenção a determinados pontos sobre a temática em estudo.

Contudo, muitas notícias nem sempre é positivo. Primeiro porque a enorme quanti-
dade faz com que o leitor prefira ler apenas manchetes e chamadas a se aprofundar
nos assuntos, o que lhe faz ter uma informação meramente superficial e que quase
nunca lhe permite compreender o que leu. Além disso, muitas vezes o título não tra-
duz toda a extensão da notícia, por isso, ler tudo é fundamental. (ANDRADE, 2018)

Nesse giro, o modo pelo qual os usuários das redes sociais as utilizam, no que se refere a leitura e compartilhamento de publicações, manifesta-se muitas vezes como um mecanismo de intensificação das Fake News, devido ao fato de que a leitura do conteúdo nesses meios, via de regra, limita-se a uma análise superficial da mensagem veiculada ou somente da manchete. Ademais, as próprias publicações, ainda que não difundam Fake News, se utilizam de recursos moralmente dúbios para atrair a atenção dos leitores, como os Clickbaits, isto é, manchetes sensacionalistas, muitas vezes duvidosas, utilizadas com o único intento de conseguir cliques e consequentemente monetização com publicidades.

\section{LIBERDADE DE EXPRESSÃO E FAKE NEWS SOB A ÓTICA DO DI- REITO BRASILEIRO}

A liberdade de expressão é um dos direitos mais intensamente assegurados na Constituição da República de 1988 isso em função do contexto histórico que dá ensejo ao surgimento da nova constituição, sobre o assunto, assevera Fernanda Carolina Torres (2013, p. 62, grifos nossos).

[...] as liberdades comunicativas não se restringem a viabilizar a participação política da população, mas também tornam possível a livre interação social no que concerne à cultura, à economia, à religião, à educação etc. Em suma, a liberdade de expressão é condição necessária ao exercício da cidadania e ao desenvolvimento democrático do Estado, na consolidação de uma sociedade bem informada e coautora de seus sistemas político e jurídico.

Complementarmente, Samantha Ribeiro Meyer-Pflug (2017, p. 72) leciona que:

3 "Relating to or denoting circumstances in which objective facts are less influential in shaping public opinion than appeals to emotion and personal belief". (OXFORD, 2016). 
O direito à liberdade de expressão do pensamento vem expressamente assegurado na Constituição Federal de 1988, o que representou a volta da democracia no Brasil e o fim do regime militar; portanto, confere especial tratamento ao Estado Democrático de Direito e assegura um amplo rol de direitos e garantias fundamentais. Nesse contexto, atribui amplo tratamento ao direito de liberdade de expressão do pensamento que é um dos alicerces do regime democrático.

A Constituição da República Federativa do Brasil estabelece, em seu texto, o direito a livre manifestação de pensamento e de expressão no artigo $5^{\circ}$, com especial foco, nos incisos IV e IX. ${ }^{4}$ Nessa linha de raciocínio, os artigos acima elencados devem ser interpretados sob a perspectiva do artigo $1^{\circ}$, III da CR/88. ${ }^{5}$ Por meio destes dispositivos, a Constituição garantiu a todo Brasileiro, nato ou naturalizado, aos estrangeiros presentes no país, o direito à livre manifestação do pensamento e expressão.

Ao atribuir tal direito, o legislador determinou, também, no texto constitucional a hipótese de um abuso desses direitos, estabelecendo conjuntamente um meio de reparação, que representa uma tentativa de estabilização das relações e a promoção da condição status quo ante por meio dos incisos V e X do artigo $5^{\circ}$ da Constituição da República. ${ }^{6}$

Logo, atrelada a questão da internet e das redes sociais, depreende-se que os sujeitos têm o direito de expressar suas opiniões no ambiente digital e de realizar publicações em tal ambiente uma vez que não extrapolem os limites impostos pela lei. Nesse sentido, na hipótese que o façam surgirá a responsabilidade pelos danos causados advindos das ações que pratiquem, de forma a reparar o dano sofrido e restaurar a normalidade das relações sociais.

O Código Civil buscou sintetizar e colmatar a responsabilidade civil em poucos artigos, sendo que os artigos 186, 187 e 927 do diploma legal traçam as diretrizes básicas da responsabilidade civil no Brasil. ${ }^{7}$ Destaca-se, em consonância com o exposto, a incidência dos artigos 20, caput e 21 do mesmo Código, ${ }^{8}$ que regulam sobre os direitos da personalidade no Brasil. Deste modo, o Direito Civil busca, também, ampliar as possibilidades de reparação do dano.

Nessa esteira, a lei civil estabelece que para além do ato ilícito constate no art. 186, uma nova modalidade é elencada no art. 187, a figura do abuso de direito. Tal hipótese é verificada quando determinado sujeito, titular de um direito subjetivo ou potestativo, o exerce para além

\footnotetext{
4 Art. $5^{\circ}$ Todos são iguais perante a lei, sem distinção de qualquer natureza, garantindo-se aos brasileiros e aos estrangeiros residentes no País a inviolabilidade do direito à vida, à liberdade, à igualdade, à segurança e à propriedade, nos termos seguintes: [...] IV - é livre a manifestação do pensamento, sendo vedado o anonimato; [...] IX - é livre a expressão da atividade intelectual, artística, científica e de comunicação, independentemente de censura ou licença; (BRASIL, 1988).

5 Art. $1^{\circ}$ A República Federativa do Brasil, formada pela união indissolúvel dos Estados e Municípios e do Distrito Federal, constitui-se em Estado Democrático de Direito e tem como fundamentos:

III - a dignidade da pessoa humana; (BRASIL, 1988).

6 V - É assegurado o direito de resposta, proporcional ao agravo, além da indenização por dano material, moral ou à imagem; [...] X - São invioláveis a intimidade, a vida privada, a honra e a imagem das pessoas, assegurado o direito a indenização pelo dano material ou moral decorrente de sua violação; (BRASIL, 1988).

7 Art. 186. Aquele que, por ação ou omissão voluntária, negligência ou imprudência, violar direito e causar dano a outrem, ainda que exclusivamente moral, comete ato ilícito. [...] Art. 187. Também comete ato ilícito o titular de um direito que, ao exercê-lo, excede manifestamente os limites impostos pelo seu fim econômico ou social, pela boa-fé ou pelos bons costumes. [...] Art. 927. Aquele que, por ato ilícito (arts. 186 e 187), causar dano a outrem, fica obrigado a repará-lo. (BRASIL, 2002).

8 Art. 20. Salvo se autorizadas, ou se necessárias à administração da justiça ou à manutenção da ordem pública, a divulgação de escritos, a transmissão da palavra, ou a publicação, a exposição ou a utilização da imagem de uma pessoa poderão ser proibidas, a seu requerimento e sem prejuízo da indenização que couber, se lhe atingirem a honra, a boa fama ou a respeitabilidade, ou se se destinarem a fins comerciais. [...] Art. 21. A vida privada da pessoa natural é inviolável, e o juiz, a requerimento do interessado, adotará as providências necessárias para impedir ou fazer cessar ato contrário a esta norma. (BRASIL, 2002).
} 
Fake news à luz da responsabilidade civil digital: o surgimento de um novo dano social

dos limites impostos pela lei, os bons costumes, fins econômico-sociais para a qual aquela situação jurídica lhe fora concedida e especialmente, a boa-fé. Destaca-se que tal figura está intimamente relacionada com a função de controle da boa-fé objetiva, ainda que conexa aos demais funções do mesmo princípio.

\title{
4. FAKE NEWS E RESPONSABILIDADE CIVIL
}

Na sociedade contemporânea o dano toma novos contornos e proporções, sendo mais facilmente verificado devido as mudanças sociais e tecnológicas contempladas.

\begin{abstract}
Dizer que os danos aumentaram em nosso século envolve certo turismo. Se nós, no início do século passado engatinhávamos nas possibilidades tecnológicas, se sequer conhecíamos a televisão ou o avião, se uma notícia demorava lentos meses para partir da Europa e até chegar até aqui, hoje, desnecessário dizê-lo, a situação modificou-se de modo impensável. É possível até afirmar, sem muito medo de errar: talvez a mais otimista das previsões não previsse que chegaríamos aonde chegamos, em possibilidades tecnológicas. (FARIAS; ROSENVALD; BRAGA NETTO, 2015, p.789).
\end{abstract}

A tecnologia, em especial, com o advento da criação da internet, modificou o modo de vida das pessoas em grande medida, desde a forma pela qual se comunicam, pelo qual interagem com as demais pessoas, a maneira que os sujeitos se informam e buscam conhecimento sobre os mais diversificados assuntos. Sob a mesma perspectiva, o dano também altera suas características assumindo novos contornos.

\begin{abstract}
Em primeiro lugar, o dano passa a tomar proporções antes nunca imaginadas. O sistema jurídico da responsabilidade civil está fundado na ideia de dano local ou dano regional. Mas tendo em vista a comunicação em massa transfronteiriça das redes sociais, a extensão do dano é muito maior. (LIMA, 2015, p. 157)
\end{abstract}

Nesse sentido, a característica comunicativa e transfronteiriça do dano em ambiente digital permite que ele se estabeleça de modo distinto das hipóteses de dano até então verificado, uma vez que a internet permite maior difusão das informações veiculadas, de modo que, o dano apresenta-se de maneira mais gravosa nesse ambiente. Neste cenário, as Fake News como fenômeno digital contemporâneo de falsidade das notícias veiculadas na internet, se inserem como um novo elemento causador de dano.

Importante ressaltar que, os indivíduos, o Estado e a sociedade, buscam evitar a ocorrência do evento danoso. Porém, no ambiente digital, tal atividade torna-se dificultosa.

\footnotetext{
O controle sempre se dá de forma posterior (em razão dos direitos de imprensa e livre expressão) à divulgação das notícias, o que permite sua propagação e desinformação, e com pouca eficiência, haja vista a existência de outras redes sociais, como WhattsApp que não possui forma de verificação de conteúdo. (ANDRADE, 2018)
}

Resta clara a dificuldade em mitigar ou extinguir as Fake News e, consequentemente, impedir a ocorrência do evento danoso derivado da disseminação das notícias falsas. A característica comunicativa e transfonteiriça da internet, bem como das redes sociais, espaços de fácil verificação de Fake News, se estabelecem como elementos ampliadores do dano, que toma proporções maximizadas em relação ao dano local.

Há de se dizer que o dano ocasionado pelas Fake News é, objetivamente, pessoal, sendo que, a notícia falsa, usualmente, causa prejuízos à dignidade da pessoa, a sua honra, atingindo assim direitos pessoais.

Ademais, a disseminação de Fake News, evidencia uma conduta, via de regra comissiva. De modo que, a publicação de uma notícia falsa ou que contenha elementos falsos é uma conduta

106 R. Jur. FA7, Fortaleza, v. 16, n. 2, p. 99-114, jul./dez. 2019 
humana comissiva. Vislumbra-se, também, a hipótese de conduta omissiva no caso de responsabilidade civil jornalística pelo descumprimento do dever de verificação ${ }^{9}$ das Fake News, quando veículos jornalísticos replicam Fake News de outras mídias.

Restou determinado que Fake News representam informações falsas, normalmente sensacionalistas, disseminadas sob o disfarce de reportagens de notícias. Deduz-se, portanto, que a dissimulação realizada quanto a veracidade da informação, isto é, o falseamento do conteúdo propagado, qualifica-se como culpa lato sensu. Outrossim, é possível vislumbrar a culpa stricto sensu, na modalidade imprudência, no que se refere à propagação das Fake News, no caso de replicação das mesmas, isto é, inobservância do dever de verificação da notícia.

\begin{abstract}
Por tudo isso, parece que a ideia de responsabilidade por danos pode ser uma importante ruptura com a perspectiva de responsabilidade civil, por se basear em outros pressupostos, quais sejam: (i) foco na vítima; (ii) pressuposto ético na alteridade; (iii) rompimento com a ideia de culpa e dolo; (iv) substituição do nexo de causalidade pela ideia de formação da circunstância danosa; (v) prioridade na precaução e na prevenção, sempre em um viés prospectivo, e a tutela dos hipervulneráveis, dos vulneráveis e dos hipossuficientes: pela resposta proporcional ao agravo e concretizadora de justiça social; (vi) mitigação das excludentes do dever de reparar. (FROTA, 2017, p. 219-220).
\end{abstract}

Deste modo, o direito dos danos ${ }^{10}$ se posiciona como uma teoria jurídica apta a resguardar os interesses do lesionado, ampliando-se o conceito de dano e minimizando as possibilidades de determinado sujeito não reparar a vítima, vez que, mitiga as possibilidades de exclusão do dever de reparar, tomando a vítima como elemento fulcral.

No que se refere a disseminação ou propagação de Fake News, verifica-se que, é evento sem o qual o dano não existe e, concorrentemente, é o evento pelo qual o dano se consuma. Sendo, deste modo, o liame causal entre a conduta de disseminar e o dano pessoal.

\title{
5. FAKE NEWS E OS NOVOS DANOS
}

Nelson Nery Junior e Rosa Maria de Andrade Nery (2018) informam que dois pontos despertam a tenção dos juristas que se ocupam do estudo da responsabilidade civil por Fake News, o dano relacionado aos crimes contra a honra e o dano que atinge os direitos civis, econômicos ou políticos. Busca-se desbravar um novo caminho no estudo da responsabilidade civil pela disseminação de Fake News, que admita a hipótese de novos danos.

A pesquisa, até este marco, focou-se em elencar os elementos basilares necessários à compreensão do fenômeno Fake News no cenário social contemporâneo, neste estudo tratado como "a era das comunicações", assim como, discutir a responsabilidade civil no que se refere as Fake News. Pretende-se, a partir deste ponto, observar a difusão de notícias falsas sob a ótica dos novos danos, analisando a existência ou inexistência de um dano social no que se refere à propagação de Fake News.

Às figuras mais comuns de dano não patrimonial (dano à integridade psicofísica, dano estético, dao à saúde etc.) vêm se somando outras, de surgimento mais recente e de classificação ainda um tanto assistemática. Para designá-las, a doutrina de toda

\footnotetext{
9 Para um estudo aprofundado da temática recomenda-se a leitura da obra "Responsabilidade Civil dos meios de comunicação" de Enéas Costa Garcia (2002).

10 "A responsabilidade por danos redescreve a linguagem da precaução, da prevenção e da reparação, com a extensão e a inovação de direitos e de deveres às vítimas, aos lesantes e (ou) responsáveis e à sociedade. O instituto esteia-se nos princípios do neminem laedere, da solidariedade social, da reparação integral e da primazia da vítima” (FROTA, 2013, p. 214)
} 
Fake news à luz da responsabilidade civil digital: o surgimento de um novo dano social

parte tem empregado expressões como novos danos ou novos tipos de danos. (SCHREIBER, 2015, p. 92)

O primeiro ponto merecedor de destaque refere-se à explanação do conceito de dano social e sua diferenciação do dano clássico, individual, patrimonial ou moral.

O dano social diferencia-se do individual em relação à pessoa que sofre a lesão, não
quanto ao conteúdo ser patrimonial ou não. Assim, um dano social pode ser patrimo-
nial (no caso, por exemplo, de uma lesão na bolsa de valores) como pode ser não
patrimonial (no caso de uma extinção de uma espécie). (FLUMIGNAN, 2015, p.204)

Tem-se que a diferenciação nuclear entre o dano social e o dano individual reside nos sujeitos lesionados por determinada conduta. Enquanto, o dano individual apresenta uma violação ao aspecto do direito individual, sendo a vítima determinada, o dano social apresenta uma violação ao aspecto do direito difuso, sendo as vítimas indeterminadas ou indetermináveis.

Um ato se doloso ou gravemente culposo, ou se negativamente exemplar, não é lesivo
somente ao patrimônio material ou moral da vítima, mas sim, atinge a toda a socie-
dade, num rebaixamento imediato do nível de vida da população. Causa dano social.
Isto é particularmente evidente quando se trate da segurança, que traz diminuição da
tranquilidade social, ou de quebra da confiança, em situações contratuais ou para-
contratuais, que acarreta redução da qualidade coletiva de vida. (AZEVEDO, 2009,
p. 377-378)

Desse modo, depreende-se que o dano social é aquele que atinge a sociedade como um todo ou em parte, rebaixando a qualidade da vida dos indivíduos enquanto integrantes desta sociedade. Há de se dizer que o rebaixamento da qualidade de vida não se refere a aspectos meramente ligados à subsistência do indivíduo, pois, em consonância com a interpretação do Supremo Tribunal Federal, a vida deve ser analisada sobre o prisma de vida digna, ampliando-se o conceito de vida e, consequentemente, dos possíveis danos direcionados a mesma. (MENDES; BRANCO, 2014, p. 255-256).

Em sentido similar, escrevem Alejandro Martínez e Urenda Sánchez (2014, p. 69):

Entendendo os direitos humanos como expressão jurídica das necessidades materiais de vida, então o direito à vida é tão somente um dos diversos direitos de que se precisa para alcançar a produção, reprodução e o desenvolvimento dela. Ainda assim, o direito à vida tem diversas facetas nessa dimensão jurídica.

Resta clara a concepção ampliativa conferida ao direito à vida, dispondo sobre a existência de diversas facetas deste direito.

Erigido o fundamento do dano social e sua correlação com a ideia de vida digna, cabe analisar se tal espécie de dano é compatível com a propagação de Fake News. O artigo 944 do Código Civil ${ }^{11}$ estabelece que a indenização se dá de acordo com a extensão do dano sofrido, contudo não identifica as possíveis espécies de dano. Buscando apresentar soluções a temática, o Enunciado n. 456 da V Jornada de Direito Civil do CJF estipulou que, a expressão "dano" inserida no artigo 944 abrange não só os danos individuais, materiais ou imateriais, mas, também, os danos sociais, difusos, coletivos e individuais homogêneos a serem reclamados pelos legitimados para propor ações coletivas (CJF, 2011).

Destarte, tem-se a propagação de Fake News como elemento causador de dano, sendo compatível com a sistemática dos danos sociais, devendo então ser analisada a existência de um dano social efetivo. Sob essa perspectiva, os conceitos de Fake News, Post Truth, bem como o de dano social devem ser considerados e correlacionados.

\footnotetext{
11 Art. 944. A indenização mede-se pela extensão do dano.
} 
As Fake News, como informações falsas e sensacionalistas disseminadas sob o disfarce de reportagens verídicas, impulsionam a Post Truth uma vez que comumente apelam a emoções e crenças dos sujeitos, com o intuito de "viralizar" e disseminar uma falsa informação, moldando a opinião pública. Sob esta ótica, verifica-se, a possiblidade de existência de um dano social na medida em que as Fake News atingem a sociedade como um todo, rebaixando a qualidade da vida dos indivíduos enquanto integrantes desta sociedade.

\begin{abstract}
Nesse cenário, o Estado tende a se preocupar cada vez mais com o controle e a veiculação de notícias falsas, ou, fake news. Isso ocorre porque o detentor da informação (especialmente dados sigilosos) poderá manipular a opinião pública, inclusive em relação a assuntos políticos e estratégicos da maior complexidade e relevância. Ampliou-se, portanto, a preocupação não só dos governantes, mas, também, dos próprios governados, em relação à disseminação de informações falsas sobre fatos e personalidades públicas relacionados ao universo político, social e econômico, de modo a influenciar negativamente a opinião pública. Ressalta-se que as informações falsas têm por objetivo desvirtuar a veracidade das informações repassadas e em grande maioria, sem que se saiba a origem do financiamento de tais notícias. Há apontamentos de ocorrência de fake news na política nacional a partir de 2010; bem como é de conhecimento público a possibilidade de manipulação das eleições de Donald Trump, nos EUA. (MARTINEZ; NASCIMENTO JUNIOR, 2018).
\end{abstract}

Sob a ótica da Post Truth, a compreensão da disseminação de Fake News como dano social torna-se incontestável, na medida em que ocorre a manipulação da opinião pública e a violação aos preceitos norteadores do princípio da boa-fé objetiva em nível social. Nesse sentido, provocam um fenômeno de ruptura social e descrença nos meios jornalísticos, que fomentam um ciclo vicioso de disseminação de Fake News por veículos alternativos de notícias que terminam por diminuir a qualidade de vida social como um todo, em especial, quando as Fake News tratam de assuntos políticos.

Como exemplo da profunda repercussão na vida das pessoas ocasionada pelas Fake News, pode-se citar a suspeita de que a disseminação de Fake News nos EUA possa ter alterado o resultado das eleições para a presidência no ano de 2016.

\begin{abstract}
Sob uma perspectiva de notícias falsas, segundo uma investigação do senado dos EUA, os russos que trabalhavam para divulgar notícias falsas visavam especificamente eleitores em estados indecisos como Wisconsin, Michigan e Pensilvânia, com essa segmentação geográfica facilitada pelos dados das mídias sociais. Além disso, de acordo com o testemunho do especialista em segurança cibernética Clint Watts, alguns desses meios de comunicação visaram explicitamente Donald Trump, twittando notícias falsas diretamente para sua conta no twitter durante períodos em que ele estava online, sob a presunção de que ele havia se mostrado particularmente suscetível a notícias falsas. Este é um exemplo extremo do ambiente de mídia altamente personalizado de hoje, aumentando as oportunidades para os fornecedores de notícias falsas alcançarem os mais prováveis e mais importantes para serem afetados pela desinformação (NAPOLI, 2018, tradução nossa). ${ }^{12}$
\end{abstract}

Suspeita-se que ambos os candidatos na corrida eleitoral tenham se utilizado de Fake News para moldar a opinião pública sobre sua pessoa e, deste modo, angariar votos nos Estados indecisos. O jornal The New York Times (2016), aponta que no mesmo período, se verificaram,

${ }^{12}$ From a false news perspective, according to a U.S. Senate investigation, the Russians working to spread fake news stories specifically targeted voters in swing states such as Wisconsin, Michigan, and Pennsylvania, with this geographic targeting facilitated by social media data. Further, according to the testimony of cyber security expert Clint Watts, some of these fake news outlets explicitly targeted Donald Trump, tweeting fake news stories directly to his Twitter account during time periods when he was known to be online, under the presumption that he has shown himself to be particularly susceptible to fake News. This is an extreme example of today's highly personalized media environment enhancing the opportunities for purveyors of fake news to reach those both most likely and most important to be affected by the misinformation. (NAPOLI, 2018). 
Fake news à luz da responsabilidade civil digital: o surgimento de um novo dano social

também, diversos sites falsos, perfis pessoais falsos em redes sociais e, até mesmo, publicações nos grandes veículos de mídia que disseminavam Fake News a favor ou desfavor dos candidatos.

Logo, depreende-se que a veiculação de Fake News não se limita a perfis falsos em redes sociais (sites) que buscam enganar leitores ou mesmo perfis pessoais, mas, também, de veículos da mídia especializada.

A eleição estadunidense de 2016 se estabeleceu como um marco no que se refere as Fake News.

\begin{abstract}
Após a eleição de 2016, uma preocupação específica tem sido o efeito de histórias falsas - "Fake News", como foi apelidado - circularam nas mídias sociais. Evidências recentes mostram que: 1) 62 por cento dos adultos norte-americanos recebem notícias nas mídias sociais; 2) as mais populares notícias falsas foram mais amplamente compartilhadas no facebook do que as notícias mais populares; 3) muitas pessoas que veem notícias falsas relatam que acreditam nelas. (ALLCOTT; GENTZKOW, 2017, tradução nossa). ${ }^{13}$
\end{abstract}

Evidencia-se, portanto, grande percentual de indivíduos que se informam somente por meio das redes sociais, espaços de profusão de Fake News, devido a liberdade de ações quase irrestrita na rede. Ao passo que, as redes sociais se apresentam como meios desconcentrados de disseminação de informações, uma série de indivíduos as utilizam com o intuito de alterar a percepção pública sobre determinados assuntos. Culmina-se, assim, na descrença nos veículos informativos, a polarização dos sujeitos e conflitos político-sociais.

Ademais, é de fundamental importância que esse estudo perpasse a legitimidade para propor a ação de reparação por danos sociais. Em consonância com a sistemática processual, temse que a legitimidade para a propositura de tal ação recai àqueles que podem mover ações coletivas de cunho reparatório em âmbito geral, e, por esta razão, excluem-se os sujeitos dispostos no art. $8^{\circ}$, inciso III da Constituição da República ${ }^{14}$, bem como, as do artigo 81, parágrafo único, inciso primeiro do Código de Defesa do Consumidor ${ }^{15}$, restando por fim aqueles presente no artigo $5^{\circ}$, inciso I da Lei $n^{\circ} 7.347 / 85$, a Lei de Ação Civil Pública ${ }^{16}$, como se extrai do voto do Ministro Luis Felipe Salomão, relator na Reclamação n.13200/GO (STJ, 2014).

Por fim, outro aspecto merecedor de destaque, refere-se à reparação pelo dano sofrido, sendo necessária analisar sua destinação, em vistas de se mitigar a possibilidade de locupletamento sem causa. Nesse seguimento, entende-se por intermédio da interpretação analógica com o art. 13, da Lei $\mathrm{n}^{\mathbf{0}} 7.347^{17}$, que o juiz deverá fixar as verbas reparatórias a título de danos sociais. Contudo, não os direcionará para as vítimas, devendo então, destiná-las a alguma instituição de proteção ao usuário ou similares, a critério do juiz.

${ }^{13}$ Following the 2016 election, a specific concern has been the effect of false Stories - "fake news, " as it has been dubbed - circulated on social media. Recent evidence shows that: 1) 62 percent of US adults get news on social media; 2) the most popular fake news stories were more widely shared on Facebook than the most popular mainstream news stories; 3) many people who see fake news stories report that they believe them. (ALLCOTT; GENTZKOW, 2017).

14 Art. $8^{\circ}$ É livre a associação profissional ou sindical, observado o seguinte: III - ao sindicato cabe a defesa dos direitos e interesses coletivos ou individuais da categoria, inclusive em questões judiciais ou administrativas;

15 Art. 81. A defesa dos interesses e direitos dos consumidores e das vítimas poderá ser exercida em juízo individualmente, ou a título coletivo.

Parágrafo único. A defesa coletiva será exercida quando se tratar de: I - interesses ou direitos difusos, assim entendidos, para efeitos deste código, os transindividuais, de natureza indivisível, de que sejam titulares pessoas indeterminadas e ligadas por circunstâncias de fato;

${ }^{16}$ Art. $5^{\circ}$ Têm legitimidade para propor a ação principal e a ação cautelar: I - o Ministério Público; II - a Defensoria Pública;

17 Art. 13. Havendo condenação em dinheiro, a indenização pelo dano causado reverterá a um fundo gerido por um Conselho Federal ou por Conselhos Estaduais de que participarão necessariamente o Ministério Público e representantes da comunidade, sendo seus recursos destinados à reconstituição dos bens lesados. 


\section{CONCLUSÃo}

O estudo buscou examinar a questão da imputação de responsabilidade civil em âmbito digital, especificamente, no que se refere aos danos causados pela disseminação e propagação de Fake News. A temática proposta, se situa em um complexo cenário, excepcionalmente amplo, tendo em vista que, o meio tecnológico se altera de forma contínua e célere criando novos meios de comunicação e exposição de ideias, e, por conseguinte, fomentando o surgimento de novos espaços de propagação de Fake News.

Dessarte, pretendeu-se investigar e analisar o fenômeno das Fake News sob a ótica comunicacional contemporânea. Nesse sentido, perpassou-se a origem e semântica do termo nuclear da pesquisa (Fake News), bem como, suas implicações no que se refere a Post Truth. Ademais, tratou-se a temática da liberdade de expressão e as hipóteses de abuso de tal direito no ordenamento jurídico brasileiro, por meio da investigação da imputação de responsabilidade civil e dos novos danos.

No que tange à inversão no polo informacional em ambiente digital, têm-se que tal fenômeno contemporâneo ocasiona a criação de dados como nunca observado anteriormente. Nesse giro, fomenta-se o exercício do direito à livre manifestação e profusão de ideias, estimulando o debate e propiciando o surgimento de meios de comunicação e informação descentralizados. Ademais, a numerosa criação de dados, informações e notícias em ambiente digital demonstrou duas facetas. A positiva, conexa ao acesso informacional e garantia do direito à liberdade de expressão. Lado outro, demonstra-se a negativa na medida em que impossibilita a verificação do conteúdo veiculado pelos diversos sujeitos, em função do grande volume de dados.

Nessa linha de intelecção, o direito à liberdade de expressão deve ser analisado, de modo que, tal como em ambiente não digital, sofre restrições e mitigações em ambiente digital. Logo, devem os indivíduos se atentarem as restrições impostas pelo Código Civil e pela própria Constituição da República.

As Fake News foram definidas como representações de informações falsas, normalmente sensacionalistas, disseminadas sob o disfarce de reportagens de notícias. Com profundo impacto na vida das pessoas, uma vez que, via de regra, têm como objeto temas polarizadores, resultando em impactos sociais e culturais. Vislumbrou-se, que a digitalização e a inversão no polo comunicacional desencadearam, em grande medida, a profusão de Fake News, sendo que as redes sociais, atuaram como catalisador desse fenômeno.

Entende-se que a circunstância danosa ensejada pela propagação de Fake News não se exterioriza somente como um dano pessoal, direcionado a sujeitos determinados aos quais as Fake News possam se referir, podendo, simultaneamente, ser observada a hipótese de ocorrência de um dano social. Nessa perspectiva, há de se levar em consideração a expansão da falsa informação, seus reflexos sociais no cenário da era das comunicações, a quebra da legítima expectativa (confiança) entre os sujeitos da sociedade e o direito fundamental do cidadão à informação.

Por fim, deve-se ponderar que as ações de reparação por Fake News, seja em função de um dano a um direito pessoal, quando a notícia falsa ofende determinado indivíduo causandolhe danos morais, materiais, ou danos sociais, por consequência da própria natureza das Fake News e sua influência no fenômeno de Post Truth, não são excludentes, uma vez que, ofendem direitos distintos e lesionam sujeitos diversos.

Deste modo, verifica-se que há a possibilidade de ações concomitantes em função do mesmo ato quando cause danos a direitos variados. Nessa esteira, nada obstando uma tutela específica em vista da proteção personalíssima do sujeito em função de danos morais e materiais, 
Fake news à luz da responsabilidade civil digital: o surgimento de um novo dano social

e autonomamente por intermédio da Defensoria Pública ou do Ministério Público, uma tutela que objetive a reparação pelo dano social causado pela ação de determinado sujeito.

\section{REFERÊNCIAS}

AFONSO, Luiz Fernando. Fake News e o direito do consumidor: uma violação ao direito fundamental à informação. In: RAIS, Diogo (Coord.) Fake News: a conexão entre a desinformação e o direito. São Paulo: Thomson Reuters Brasil, 2018. [E-book]

ALLCOTT, Hunt; GENTZKOW, Matthew. Social Media and Fake News in the 2016 Election. Journal of Economic Perspectives. vol. 31, n. 2, 2017. [E-book]

ANDRADE, Campos Renato. Os danos causados pelas Fake News. Abril, 2018. Disponível em: https://domtotal.com/noticia/1247948/2018/04/os-danos-causados-pelas-fake-news/ Acesso em: 23 jun. 2018.

AZEVEDO, Antônio Junqueira de. Novos Estudos e Pareceres de Direito Privado. São Paulo: Saraiva, 2009.

BRASIL. Lei $\mathbf{n}^{\mathbf{0}}$ 7.347, de 24 de julho de 1985. Disponível em: http://www.planalto.gov.br/ccivil_03/LEIS/L7347orig.htm Acesso em: 17 jun. 2018.

BRASIL. Constituição da República Federativa do Brasil, de 5 de outubro de 1988. Disponível em: http://www.planalto.gov.br/ccivil_03/Constituicao/ConstituicaoCompilado.htm Acesso em: 25 jun. 2018.

BRASIL. Código Civil. Lei no 10.406, de 10 de janeiro de 2002. Disponível em: http://www.planalto.gov.br/ccivil_03/LEIS/2002/L10406.htm Acesso em: 26 jun. 2018.

BRASIL, STJ (Superior Tribunal de Justiça). Rcl: 13200 GO 2013/0197835-7, Relator: Ministro Luis Felipe Salomão. DJ: 08/10/2014, S2 - Segunda Seção, DP: DJe 14/11/2014.

COLLINS, Dictionary. Word of the Year 2017. Disponível em: https://www.collinsdictionary.com/woty. Acesso em: 08 abr. 2018.

CJF (Conselho de Justiça Federal). V Jornada de Direito Civil - Enunciado 456. 2011. Disponível em: http://www.cjf.jus.br/enunciados/enunciado/403 Acesso em: 20 jun. 2018.

CORRÊA, Fabiano Simões. Um estudo qualitativo sobre as representações utilizadas por professores e alunos para significar o uso da Internet. 2013. 172 f. Dissertação (Dissertação em Psicologia) - Departamento de Psicologia. Universidade de São Paulo. São Paulo, São Paulo.

FARIAS, Cristiano Chaves de; ROSENVALD, Nelson; BRAGA NETTO, Felipe Peixoto. Novo Tratado de Responsabilidade Civil. São Paulo: Atlas, 2015.

FLUMIGNAN, Silvano José Gomes. A distinção entre dano moral, dano social e punitive damages a partir do conceito de dano-evento e dano-prejuízo: O início da discussão. Revista Acadêmica da Faculdade de Direito do Recife. Universidade Federal de Pernambuco, v. 87, p. 190-219, 2015.

FOLHA DE SÃO PAULO. Notícias falsas existem desde o século 6, afirma historiador Robert Darnton. Fevereiro, 2017. Disponível em: https://www1.folha.uol.com.br/ilustrissima/ 2017/02/1859726-noticias-falsas-existem-desde-o-seculo-6-afirma-historiador-robert-darnton.shtml Acesso em: 15 mai. 2018. 
FROTA, Pablo Malheiros da Cunha. Imputação sem nexo causal e a responsabilidade por danos. 2013. 275 f. Tese (Doutorado em Direito) - Faculdade de Direito. Universidade Federal do Paraná. Curitiba, Paraná.

FROTA, Pablo Malheiros da Cunha. Responsabilidade Civil por danos e a superação da ideia da responsabilidade civil: reflexões. In: ROSENVALD, Nelson; MILAGRES, Marcelo. Responsabilidade Civil: Novas Tendências. Indaiatuba: Foco Jurídico, 2017, p. 211-227.

GARCIA, Enéas Costa. Responsabilidade Civil dos meios de comunicação. São Paulo: Juarez de Oliveira, 2002.

GUSTIN, Miracy Barbosa de Sousa; DIAS, Maria Tereza Fonseca. (Re)pensando a pesquisa jurídica: teoria e prática. 3. ed. Belo Horizonte: Del Rey, 2010.

IBM MARKETING CLOUD. 10 key marketing trends for 2017 and ideas for Exceeding Customer Expectations. 2017. Disponível em: https://public.dhe.ibm.com/common/ssi/ecm/ wr/en/wrl12345usen/watson-customer-engagement-watson-marketing-wr-other-papers-and-reports-wrl12345usen-20170719.pdf. Acesso em: 23 jun. 2018.

KLEIN, David; WUELLER, Joshua. Fake News: A Legal Perspective. United States Law Articles in English. 2017. [Ebook]

LIMA, Cintia Rosa Pereira de. A reponsabilidade civil dos provedores de aplicação de internet por conteúdo gerado por terceiro antes e depois do Marco Civil da Internet (lei n ${ }^{\circ}$ 12.965/14). Revista da Faculdade de Direito. Universidade de São Paulo, São Paulo, v. 110, p. 155-176, 2015.

MARANHÃO, Juliano; CAMPOS, Ricardo. Fake News e autoregulamentação regulada das redes sociais no Brasil: fundamentos constitucionais. In: ABBOUD, Georges; NERY JUNIOR, Nelson; CAMPOS, Ricardo. Fake News e Regulação. São Paulo: Thomson Reuters Brasil, 2018, p. 217-.231

MARTÍNEZ, Alejandro Rosillo; SÁNCHEZ, Urenda Queletzú Navaro. A dupla dimensão da vida nos direitos humanos: como fundamento e como direito. Meritum: revista de direito da Universidade FUMEC. Universidade FUMEC, Belo Horizonte, v. 9, n. 2, p. 41-75, 2014.

MARTINEZ, Vinício Carrilho; NASCIMENTO JUNIOR, Vanderlei de Freitas. Participação popular, redes sociais e fake news: uma abordagem constitucional antes das eleições 2018. Revista dos Tribunais. v. 993, p.179-199, 2018. [E-book]

MENDES, Gilmar Ferreira; BRANCO, Paulo Gustavo Gonet. Curso de Direito Constitucional. 9. ed. São Paulo: Saraiva, 2014.

MEYER-PFLUG, Samantha Ribeiro. Liberdade de expressão do pensamento. In: LEITE, George Salomão; LEITE, Glauco Salomão; STRECK, Lenio Luiz (Coord.). Jurisdição constitucional e liberdades públicas. Belo Horizonte: Fórum, 2017, p. 71-85.

NAPOLI, Philip. What if more speech is no longer the solution? First Amendment Theory meets Fake News and the Filter Bubble. Federal Communication Law Journal. vol. 70, n. 1, 2018. [E-book]

NERY JUNIOR, Nelson; NERY, Rosa Maria de Andrade. Confiança na mídia: responsabilidade civil por danos causados por Fake News. In: ABBOUD, Georges; NERY JUNIOR, Nelson; CAMPOS, Ricardo. Fake News e Regulação. São Paulo: Thomson Reuters Brasil, 2018, p. 109122. 
OXFORD, Dictionary. Word of the Year 2016. Disponível em: https://www.oxforddictionari es.com/press/news/2016/12/11/WOTY-16 Acesso em: 08 abr. 2018.

SCHREIBER, Anderson. Novos paradigmas da responsabilidade civil. 6. ed. São Paulo: Atlas, 2015.

SIQUEIRA, Dirceu Pereira; NUNES, Danilo Henrique. Conflitos digitais: cidadania e responsabilidade civil no âmbito das lides cibernéticas. Revista Jurídica da FA7. Centro Universitário 7 de Setembro, Fortaleza, v. 15, n. 2, 2018, p. 127-138.

SILVEIRA, Michele Marinho da et al. Educação e inclusão digital para idosos. Revista RENOTE - Novas Tecnologias na Educação. UFRGS, Universidade Federal do Rio Grande do Sul, Porto Alegre, v. 8, n. 2, 2010.

TEFFÉ, Chiara Spadaccini de; SOUZA, Carlos Affonso Pereira de. Fake News: Como garantir liberdades e conter notícias falsas na internet. In: TEPEDINO, Gustavo; MENEZES, Joyceane Bezerra de. Autonomia Privada, Liberdade Existencial e Direitos fundamentais. Belo Horizonte: Fórum, 2019, p. 525-543.

THE NEW YORK TIMES. The Hoaxes, Fake News and Misinformation We Saw on Election Day. Nov, 2016. Disponível em: https://www.nytimes.com/2016/11/09/us/politics/debunkfake-news-election-day.html Acesso em: 27 jun. 2018.

THE WALL STREET JOURNAL. YouTube Tops 1 Billion Hours of Video a Day, on Pace to Eclipse TV. Feb, 2017. Disponível em: https://www.wsj.com/articles/youtube-tops-1-billionhours-of-video-a-day-on-pace-to-eclipse-tv-1488220851 Acesso em: 24 jun. 2018.

TORRES. Fernanda Carolina. O direito fundamental à liberdade de expressão e sua extensão. Revista de Informação Legislativa, Brasília, ano 50, n. 200, out./dez. 2013. Disponível em: www2.senado.leg.br/bdsf/item/id/502937. Acesso em: 13 dez. 2017.

WITKER, Jorge. Como elaborar una tesis en derecho: pautas metodológicas y técnicas para el estudiante o investigador del derecho. Madrid: Civitas, 1985.

Recebido em: 25 abr. 2019.

Aceito em: 9 ago. 2019. 